\title{
Status of body symmetries of youth judokas in -73kg category
}

\author{
Jožef ŠIMENKO*
}

University of Ljubljana, Faculty of Sport, Institute of Sport\& Department of Combat Sports (Slovenia)

\section{Introduction}

Conventional anthropometry is the most known and used method for assessing the dimensions of body segments (Heyward \& Wagner, 2004), and it is also often used in judo (Franchini, Del Vecchio, Matsushigue, \& Artioli, 2011; Katralli \& Goudar, 2012). The progress of technology and application of 3D body scanners has taken anthropometry research to a new direction as those methods have become contactless, fast and above all, accurate (Simmons \& Istook, 2003; Zhang, et al., 2014) and are increasingly widely used in judo (Šimenko \& Vodičar, 2015; Šimenko, 2015a,b). Body dimensions play an important component in weight-sensitive sports (Clarys, Geelen, Aerenhouts, Deriemaeker, \& Zinzen, 2011), therefore 3D analysis can also be useful in determining body asymmetries which can lead to occurrence of injuries (Šimenko \& Vodičar, 2015). The present study seeks to examine the status of the body symmetries in youth judokas in the under $73 \mathrm{~kg}$ category.

\section{Methodology}

Ten youth Slovenian judokas participated in this study, 5 with 1.Dan and 5 with 1.Kyu belt degree (age: $17.28 \pm 1.46$ years; height: $177.53 \pm 3.71 \mathrm{~cm}$; weight: $73.86 \pm 3.01 \mathrm{~kg}$ ), that are competing in under $73 \mathrm{~kg}$ category in cadet and/or junior age category in domestic and international tournaments. Two of them were left hand dominant and eight of them were right hand dominant. 3D anthropometric measurement of judokas body was performed by the 3D body scanner NX-16 ([TC $]^{2}$, Cary, North Carolina). The NX-16 utilizes a non-invasive scanning method to produce a trueto-scale 3D body model in 8 seconds, which uses photogrammetry technology (white light) with 32 cameras to produce raw photonic point cloud data 3D body image. That 3D cloud data image allows for automatic landmark recognition as well as electronic tape measurements. Before measurements full calibration of the NX-16 scanner was made, with the acceptable range of the accuracy of circumferences standard deviation of $0.577 \mathrm{~mm}$. Subjects were instructed to remove all jewelry and clothes. They entered the scanner barefooted and in form-fitting bright color underwear. They stood in a standardized position, with their feet located on landmarks on the scanner's floor (feet set straight, not inwards or outwards), grabbing the handles inside of the scanner with a natural standing posture (shoulders not elevated, elbows stretched, upright position of the back, chin slightly lifted). A 3D Body Measurement System Version 7.4.1 software was used to create the initial point cloud that was then processed into a 3D body model from which customized measurements could be extracted. A multi-scan option with three consecutive scans was used to obtain the data which gave us one merged file with means of all three consecutive scans. Scanning of three consecutive scans lasted $24 \mathrm{~s}$ and subjects were instructed to be still as much as possible. With software we extracted values of 15 paired variables: left (L) and right (R) armscye girth, L-R straight arm length, L-R upper arm girth, L-R elbow girth, L-R forearm girth, L-R wrist girth, L-R side height waist to flor, L-R outside leg length, L-R thigh length, L-R thigh girth, L-R mid-thigh height, L-R mid-thigh girt, L-R knee height, L-R knee girth and L-R calf girth. Data were analyzed 
with the SPSS 22.0 software for Windows. For determination of differences in symmetries we used a two-paired t-Test with statistical significance set at $p \leq 0.05$.

\section{Results}

Statistically significant differences between right and left variables were elbow girth (EGR, EGL) $\mathrm{t}(9)=4.08, \mathrm{p}=0.003$, forearm girth (FGR, FGL) $\mathrm{t}(9)=2.84, \mathrm{p}=0.019$, thigh girth $(\mathrm{TGR}, \mathrm{TGL}) \mathrm{t}(9)=$ $3.88, \mathrm{p}=0.004$, mid-thigh girth (MTGR, MTGL) $\mathrm{t}(9)=5.81, \mathrm{p}=0.000$ and calf girth (CGR, CGL) $\mathrm{t}(9)=$ $2.45, \mathrm{p}=0.037$. Variables that are not statistically significant, but are closest to the $p \leq 0.05$ limit were knee height $($ KHR, KHL) $\mathrm{t}(9)=2.00, \mathrm{p}=0.077$, mid-thigh height $($ MTHR,MTHL) $\mathrm{t}(9)=2.08, \mathrm{p}=$ 0.068 and calf height (CHR, CHL) $\mathrm{t}(9)=2.16, \mathrm{p}=0.059$. The rest of the variables were not statistically significant.

\section{Discussion and conclusion}

Results show that youth judokas in under 73kg category statistically differ in five of 15 selected variables and with three variables on the limit of significance. These results show that, in this weight category, some body asymmetries start to occur, which can significantly contribute to the occurrence of injuries if they develop excessively. Usually, asymmetries are consequences of extended lateral training that starts to occur in youth judokas, especially in those that start to compete internationally. Those judokas are starting to develop their tokui-waza (special technique), therefore, coaches should enforce the development of the bilateral execution of those techniques to increase the motor efficiency of judokas and consequently increase their technicaltactical solutions in fight and specially to reduce the possibilities of injuries occurring. All previously listed factors will help to reduce the dropout rate and contribute to a systematic development of youth athletes into senior judokas.

\section{References}

Clarys, P., Geelen, B., Aerenhouts, D., Deriemaeker, P., \& Zinzen, E. (2011). Estimation of body composition in adolescent judo athletes. Journal of Combat Sports and Martial Arts, 2(2), 73-77.

Franchini, E., Del Vecchio, F. B., Matsushigue, K. A., \& Artioli, G. G. (2011). Physiological Profiles of Elite Judo Athlets. Sports Medicine, 41(2), 147-166.

Heyward, V. H., \& Wagner, D. R. (2004). Applied body composition assessment. United States of America: Human Kinetics.

Katralli, J., \& Goudar, S. S. (2012). Anthropometric Profile and Special Judo Fitness levels of Indian Judo Players. Asian Journal of Sports Medicine, 3(2), 113-118.

Simmons, K. P., \& Istook, C. L. (2003). Body measurement techniques: A comparison of threedimensional body scanning and physical anthropometric methods for apparel application. Journal of Fashion Marketing and Management, 7(3), 306-332.

Zhang, K., Zheng, J., Gao, C., Thomas, D., Li, X., \& Heymsfield, S. (2014). Rapid-accurate anthropometric body shape assessment with low-cost novel 3D imaging system (391.2). The FASEB Journal, 28(1, Supplement).

Šimenko, J. (2015a). Usage of 3D body scanning technology in judo. In: H. Sertič, S. Čorak, \& I. Segedi (Eds.), Applicable research in judo: Book of Abstract. $1^{\text {st }}$ Scientific and professional conference on judo, Zagreb, Croatia, 13-14 February 2015 (pp. 20-21). Zagreb: University of Zagreb, Faculty of Kinesiology.

Šimenko, J. (2015b). Impact of directional asymmetry on competition performance in judo: a pilot study. In: H. Sertič, S. Čorak, \& I. Segedi (Eds.), Applicable research in judo: Book of Abstract. $1^{\text {st }}$ Scientific and professional conference on judo, Zagreb, Croatia, 13-14 February 2015 (pp. 22-23). Zagreb: University of Zagreb, Faculty of Kinesiology.

Šimenko, J., \& Vodičar, J. (2015). Evaluation of body symmetries in judo. In: M. Doupona Topič, \& T. Kajtna (Eds.) Youth sport: Proceedings book / 7th Conference for Youth Sport, Ljubljana, 12-13 December 2014 (pp. 138-143). Ljubljana: Fakultetaza Šport

Key words: 3D scanning; anthropometry; combat sports; judo; asymmetry. 